\title{
The metal concentrations in several fish species on the coast of Muara Gembong, Bekasi Regency, West Java, Indonesia
}

\author{
Adriani S. Nastiti ${ }^{1,}$, Dimas A. Hediato ${ }^{1}$, Masayu R. A. Putri ${ }^{1}, \mathrm{Krismono}^{1}$ \\ ${ }^{1}$ Research Institute for Fisheries Enhancement (RIFE), Ministry of Marine Affairs and Fisheries, Jl. \\ Cilalawi No. 01 Jatiluhur, Purwakarta, West Java 41152 - Indonesia
}

\begin{abstract}
Muara Gembong Beach is part of the eastern area of Jakarta Bay which is still a source of fish consumption for the local community. This study aims to present information about the concentration of metals in several types of fish. The study was conducted in October 2018 at 5 stations, namely the Citarum River, Muara Bendera, Pulau Buaya, Muara Blacan, and Muara Jaya. The parameters measured were copper $(\mathrm{Cu})$, cadmium $(\mathrm{Cd})$, Chromium $(\mathrm{Cr})$, lead $(\mathrm{Pb})$, Zinc $(\mathrm{Zn})$, mercury $(\mathrm{Hg})$, and Arsen (As) in several types of fish consumption sizes, with the local names Kuro (Eleutheronema tetradactylum), Keropak (Hexanematichthys sagor), Bloso (Glossogobius giuris), Samgeh (Nibea soldado), Shrimp (Macrobrachium rosenbergii), Mujair (Oreochromis mossambicus), Patin (Pangasianodon hypophthalmus), and detected in fish samples. Zn was detected in all fish samples and research stations, while $\mathrm{Cu}$ was detected in shrimp in Muara Blacan and Muara Flag. As detected in Kuro in Muara Jaya, Mujair in Muara Blacan, Shrimp in Muara Bendera. The concentration of $\mathrm{Zn}, \mathrm{As}$, and $\mathrm{Cu}$ has exceeded the quality standard in biota. Prevention of the entry of waste containing metals into waters, among others, through increasing public regulations and strict sanctions from the government.
\end{abstract}

\section{Introduction}

The coast of Muara Gembong is an area east of Jakarta Bay. Muara Gembong is still a source of consumption fish for the surrounding community. However, its waters have been degraded by identifying several types of metals both in the waters and in the bottom substrate [1,2]. This degradation results in contamination of consumption fish. Therefore, it is crucial to monitor the concentration of metals in waters, sediments, and their biota. Metals are produced from natural and anthropogenic activities [3]. Metals are divided into non-essential and essential. Non-essential metals, for example, aluminum ( $\mathrm{Al})$, cadmium $(\mathrm{Cd})$, mercury $(\mathrm{Hg})$, tin $(\mathrm{Sn})$, and lead $(\mathrm{Pb})$ have no proven biological function (also called xenobiotics or foreign elements), and their toxicity increases with increasing concentration [4]. Essential metals, for example, copper $(\mathrm{Cu})$, zinc $(\mathrm{Zn})$, chromium $(\mathrm{Cr})$, nickel $(\mathrm{Ni})$, cobalt $(\mathrm{Co})$, molybdenum $(\mathrm{Mo})$, and iron $(\mathrm{Fe}))$ on the other hand, have biological roles [5]. Metal toxicity has proven

\footnotetext{
1*Corresponding author: adrin0506@yahoo.co.id
} 
to be a significant threat, and there are several health risks associated with it [6]. Metals are environmental pollutants known for their toxicity, persistence in the environment, and bioaccumulative properties.

Metal pollution both in the environment and biota through the food cycle can affect human health [7]. The nature of metals that do not decompose, causing accumulation in certain media or objects. Geochemical processes of metal contaminants can occur within a certain period $[7,8]$. The following geochemical process that occurs in the sea is dynamics, in which fish and various other biota interact with each other. Eventually, these fish and biota are declared contaminated with toxic metals.

Some of the fish caught by fishermen are consumed and sold to the broader community due to exposure to metal contaminants, e.g., lead, arsenic, mercury, chromium, nickel, and other toxic metals are widely distributed in Public. This condition must be prevented early on from upstream to downstream by applying various methods, is bioabsorption [9-11]. The biological activities of fish are very vulnerable in polluted aquatic environments [1-3]. Accumulation of metals in fish meat from environmental pollution through digestion. Indicators of metal pollution in the world's environment can be known by monitoring indicators of organisms, such as insects, fish, plankton, and bacteria [12]. Metals accumulated in the fish and other aquatic organisms in direct and indirect accumulation, consumption of contaminated water and food through the digestive system considered direct exposure or indirectly through the porous membranes such as skin and gills. The level of metals concentration in fish and other aquatic organisms' organs indicates their levels also in their surrounding environment [13]. Metals in waters have an impact on aquatic organisms as well as humans. One of the impacts was the mass fish mortality that occurred in Jakarta Bay in 2004. The metal content in Jakarta Bay is high, so it is dangerous for aquatic organisms. Metals that enter the human body are also hazardous for health. Metals can block the work of enzymes so that the body's metabolism is disrupted cause cancer and mutations. Some hazardous metals for humans include lead, copper, mercury, cadmium, and chromium [14].

The purpose of the study was to provide information on the concentration of several types of fish on the coast of Muara Gembong and alternative remedies.

\section{Materials and methods}

\subsection{Location and time}

The research was conducted in October 2018, fish samples[15,16,17] each species as many as three fish were taken at five stations; Citarum River, Muara Bendera, Pulau Buaya, Muara Blacan, and Muara Jaya (Fig.1. and Table 1). 


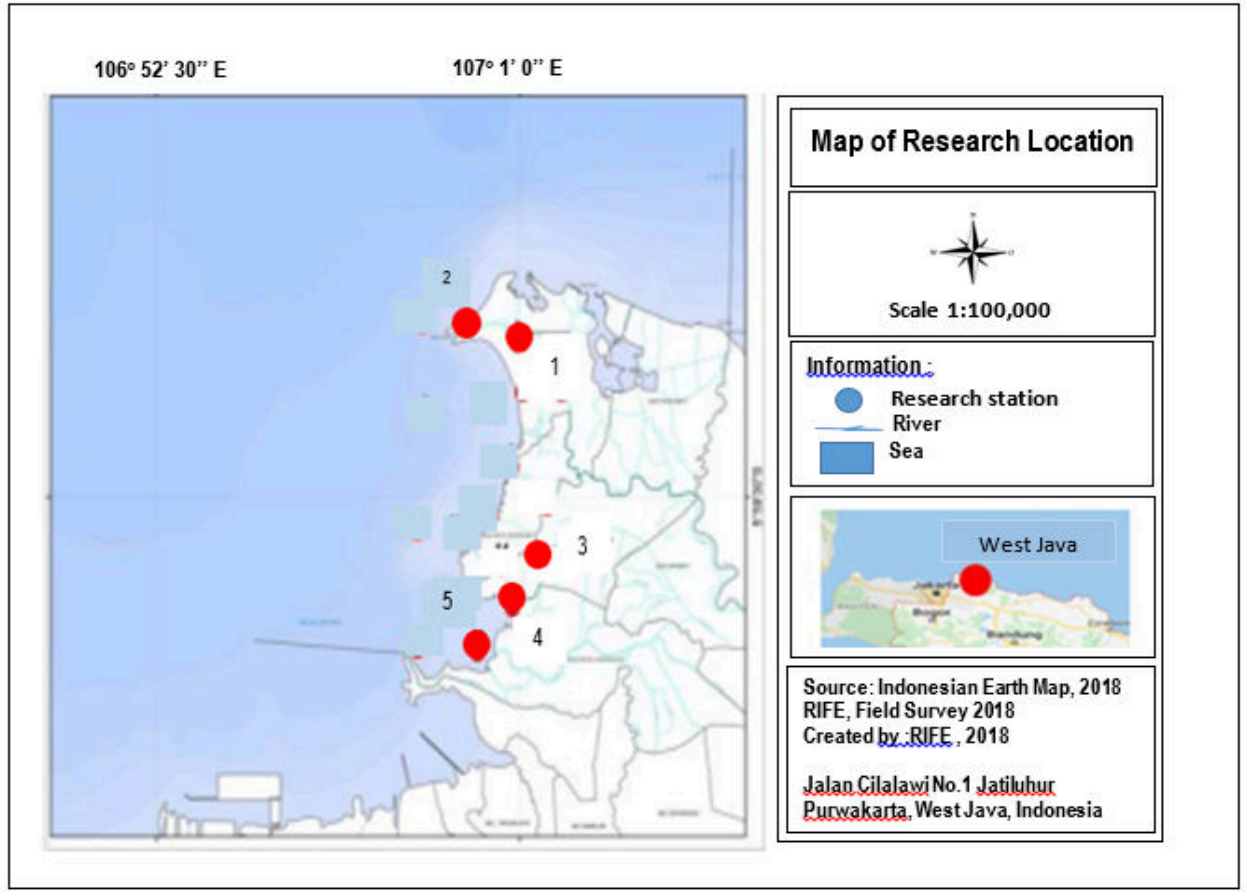

Fig. 1. Map of research stations

Table 1. Geographical position and description of the research station.

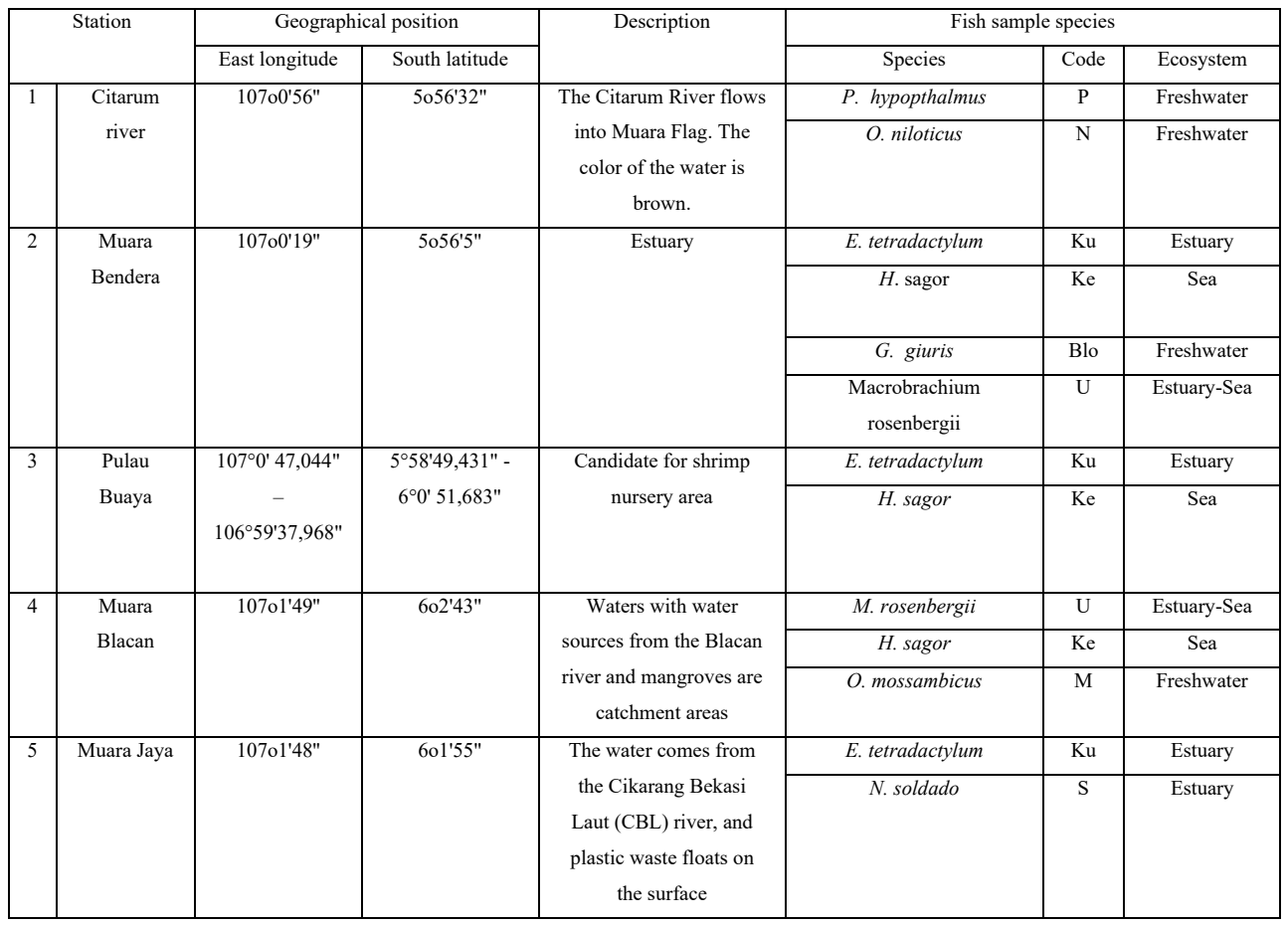




\subsection{Methods}

Fish samples analyzed were obtained from catches using experimental gill nets. Fish samples were selected that represent their habitats, namely rivers (freshwater), estuaries, marineestuaries, and seas. The tissue of samples from each fish species was taken, weighing 10 grams wrapped in aluminum foil. The samples were stored in a cool box, and then the samples were analyzed for metals $(\mathrm{Cu}, \mathrm{Cd}, \mathrm{Cr}, \mathrm{Pb}, \mathrm{Zn}, \mathrm{Hg}$, and $\mathrm{As})$. Metal analysis using AAS (Atomic Absorption Spectrophotometry) with limit detection (Table 2) referring to ISO 17025:2017 at the Saraswati Indo Genetech Laboratory, Bogor, Indonesia.

Table 2. Metal limit detection.

\begin{tabular}{|l|l|l|l|}
\hline \multicolumn{2}{|c|}{ Metal } & Unit & Limit detection \\
\hline 1 & $\mathrm{Cu}$ (Cuprum) & $\mathrm{mg} / \mathrm{kg}$ & 0.13 \\
\hline 2 & $\mathrm{Cd}$ (Cadmium) & $\mathrm{mg} / \mathrm{kg}$ & 0.00011 \\
\hline 3 & $\mathrm{Cr}$ (Chromium hexavalent) & $\mathrm{mg} / \mathrm{kg}$ & 0.0012 \\
\hline 4 & $\mathrm{~Pb}$ (Plumbum) & $\mathrm{mg} / \mathrm{kg}$ & 0.009 \\
\hline 5 & $\mathrm{Zn}$ (Zinc) & $\mathrm{mg} / \mathrm{kg}$ & 0.136 \\
\hline 6 & $\mathrm{Hg}$ (Mercury) & $\mathrm{mg} / \mathrm{kg}$ & 0.004 \\
\hline 7 & $\mathrm{As}$ (Arsen) & $\mathrm{mg} / \mathrm{kg}$ & 0.008 \\
\hline
\end{tabular}

\subsection{Data analysis}

The level of safety of fish from metal content was determined by comparing the results of the concentration of metals from each type of fish with the quality standards for metal concentrations. These quality standards include:

(a). Based on Decree of the State Minister of Environment Number: 51 the year 2004 concerning seawater quality standard [20].

Table 3. Decree of the State Minister of Environment Number: 51 the year 2004 concerning seawater quality standard.

\begin{tabular}{|l|l|l|l|}
\hline \multicolumn{2}{|c|}{ Metal } & \multicolumn{1}{c|}{ Unit } & \multicolumn{1}{c|}{ Quality standard } \\
\hline 1 & $\mathrm{Cu}$ (Cuprum) & $\mathrm{mg} / \mathrm{L}$ & 0.008 \\
\hline 2 & $\mathrm{Cd}$ (Cadmium) & $\mathrm{mg} / \mathrm{L}$ & 0.001 \\
\hline 3 & $\mathrm{Cr}$ (Chromium hexavalent) & $\mathrm{mg} / \mathrm{L}$ & 0.005 \\
\hline 4 & $\mathrm{~Pb}$ (Plumbum) & $\mathrm{mg} / \mathrm{L}$ & 0.008 \\
\hline 5 & $\mathrm{Zn}$ (Zinc) & $\mathrm{mg} / \mathrm{L}$ & 0.05 \\
\hline 6 & $\mathrm{Hg}$ (Mercury) & $\mathrm{mg} / \mathrm{L}$ & 0.01 \\
\hline 7 & $\mathrm{As}$ (Arsen) & $\mathrm{mg} / \mathrm{L}$ & 0.012 \\
\hline
\end{tabular}

(b). Base on Indonesian National Standard (SNI) National Standardization Agency (BSNi) ICS.67.220.20 [21]

Table 4. Maximum limit of metal contamination in fish food.

\begin{tabular}{|l|l|c|c|c|c|c|c|}
\hline Food category & \multirow{2}{*}{$\begin{array}{l}\text { Food category } \\
\text { number }\end{array}$} & \multicolumn{4}{|c|}{ Maximum limit $(\mathrm{mg} / \mathrm{kg})$} \\
\cline { 3 - 7 } & & $\mathrm{Cd}$ & $\mathrm{Pb}$ & $\mathrm{Hg}$ & $\mathrm{As}$ & $\mathrm{Cd}$ \\
\hline \multirow{5}{*}{09.0} & Fish and processed & 0.1 & 0.3 & 0.5 & 1.0 & 0.1 \\
\cline { 2 - 7 } & Shellfish (bivalves) mollusks, sea cucumbers & 1.0 & 1.5 & 1.0 & 1.0 & 1.0 \\
\cline { 2 - 7 } & Shrimp and other crustaceans & 1.0 & 0.5 & 1.0 & 1.0 & 1.0 \\
\cline { 2 - 7 } & Predatory fish (tail fish, tuna, marlin, etc.) & 0.5 & 0.4 & 1.0 & & 0.5 \\
\cline { 2 - 7 } & Shrimp paste & & 1.0 & & & \\
\hline
\end{tabular}




\section{Results and discussion}

\subsection{Results}

The concentrations of metals detected in fish in Muara Gembong in October 2018 are listed in Table 4. There are three types of metals detected in fish meat: $\mathrm{Zn}$, As, and $\mathrm{Cu}$. $\mathrm{Zn}$ metal was detected exceeding the quality standard $(0.05 \mathrm{mg} / \mathrm{kg})$ in all types of fish samples and all research stations in the range of $2.9-15.17 \mathrm{mg} / \mathrm{kg}$. The highest concentration was 12.1-15.17 $\mathrm{mg} / \mathrm{kg}$ detected in Macrobrachium rosenbergii in Muara Bendera and Muara Blacan. The lowest concentration ranged from $2.9-3.76 \mathrm{mg} / \mathrm{kg}$ was detected in Pangasius hypopthalmus in Muara Bendera and Nibeo soldado in Muara Jaya. metal Cu (Cuprum) was detected in Macrobrachium rosenbergii in Muara Bendera $6.96 \mathrm{mg} / \mathrm{kg}$ and Muara Blacan at $3.41 \mathrm{mg} / \mathrm{kg}$ (Table 4), which exceeded the quality standard. Metal As (Arsenic) was detected in Macrobrachium rosenbergii, Oreochromis mossambicus, and Eleutheronema tetradactylum respectively: $1.64 \mathrm{mg} / \mathrm{kg}, ; 1.80 \mathrm{mg} / \mathrm{kg}$; and $1.63 \mathrm{mg} / \mathrm{kg}$ (Table 4) which exceeds the quality standard $(0.012 \mathrm{mg} / \mathrm{kg})$. However, metals $\mathrm{Cd}, \mathrm{Cr}, \mathrm{Pb}$, and $\mathrm{Hg}$ were not detected in fish tissue samples at Muara Gembong in October 2018 (Table 5). 
Table 5. Concentration of metal on fish species in several research station.

\begin{tabular}{|c|c|c|c|c|c|c|c|c|c|c|c|c|c|c|c|c|}
\hline \multicolumn{2}{|c|}{ Metal } & \multirow{3}{*}{$\begin{array}{l}\text { Quality } \\
\text { standard } \\
(\mathrm{mg} / \mathrm{kg}) *\end{array}$} & \multicolumn{14}{|c|}{ Concentration of metal $(\mathrm{mg} / \mathrm{kg})$ on species : } \\
\hline & & & \multicolumn{2}{|c|}{ Citarum river } & \multicolumn{5}{|c|}{ Muara Bendera } & \multicolumn{2}{|c|}{ Pulau Buaya } & \multicolumn{3}{|c|}{ Muara Blacan } & \multicolumn{2}{|c|}{ Muara Jaya } \\
\hline & & & $\mathrm{P}$ & $\mathrm{N}$ & $\mathrm{Ku}$ & $\mathrm{Ke}$ & Blo & $\mathrm{S}$ & $\mathrm{U}$ & $\mathrm{Ku}$ & $\mathrm{Ke}$ & $\mathrm{U}$ & $\mathrm{Ke}$ & $\mathrm{Mu}$ & $\mathrm{S}$ & $\mathrm{Ku}$ \\
\hline $\mathrm{Cu}$ & & 0.008 & nd & nd & nd & nd & nd & nd & 6.96 & nd & nd & 3.41 & nd & nd & nd & nd \\
\hline $\mathrm{Cd}$ & & 0.001 & nd & nd & nd & nd & nd & nd & nd & nd & nd & nd & nd & nd & nd & nd \\
\hline $\mathrm{Cr}$ & & 0.005 & nd & nd & nd & nd & nd & nd & nd & nd & nd & nd & nd & nd & nd & nd \\
\hline $\mathrm{Pb}$ & & 0.008 & $\mathrm{nd}$ & nd & $\mathrm{nd}$ & nd & nd & nd & nd & nd & $\mathrm{nd}$ & nd & $\mathrm{nd}$ & nd & nd & nd \\
\hline $\mathrm{Zn}$ & & 0.05 & 2.9 & 4.87 & 4.96 & 7.30 & 6.26 & 5.47 & 15.17 & 5.97 & 5.97 & 12.1 & 5.72 & 5.79 & 3.76 & 4.64 \\
\hline $\mathrm{Hg}$ & & 0.01 & nd & nd & nd & nd & nd & nd & nd & nd & nd & nd & nd & nd & nd & nd \\
\hline As & & 0.012 & nd & nd & nd & nd & nd & nd & 1.64 & nd & nd & nd & nd & 1.80 & nd & 1.63 \\
\hline \multicolumn{17}{|l|}{ Note: } \\
\hline$P$ & : & \multicolumn{15}{|c|}{ Pangasius hypopthalmus } \\
\hline $\mathrm{N}$ & : & \multicolumn{15}{|c|}{$\begin{array}{l}\text { Pangasius nypopthalmus } \\
\text { Oreochromis niloticus }\end{array}$} \\
\hline nd & : & \multicolumn{15}{|c|}{ No detection } \\
\hline $\mathrm{Ku}$ & : & \multicolumn{15}{|c|}{ Eleutheronema tetradactylum } \\
\hline $\mathrm{Ke}$ & : & \multicolumn{15}{|c|}{ Hexanematichthys sagor } \\
\hline Blo & : & \multicolumn{15}{|c|}{ Glossogobius giuris } \\
\hline $\mathrm{S}$ & : & \multicolumn{15}{|c|}{ Nibea soldado } \\
\hline $\mathrm{U}$ & : & \multicolumn{15}{|c|}{ Macrobrachium rosenbergii } \\
\hline $\mathrm{Mu}$ & : & \multicolumn{15}{|c|}{ Oreochromis mossambicus. } \\
\hline *) & . & \multicolumn{15}{|c|}{ Decree of the state Minister of Environment Number: 51 the year 2004 concerning sea water quality standard } \\
\hline
\end{tabular}


The safety of fish as consumption fish based on the Indonesian National Standard (SNI) can be seen in Table 6 .

Table 6. Safety status of fish and shrimp consumption in Muara Gembong.

\begin{tabular}{|l|l|l|l|l|l|l|l|l|l|}
\hline \multirow{2}{*}{$\begin{array}{l}\text { Food } \\
\text { category } \\
\text { number }\end{array}$} & Food category & \multicolumn{4}{|c|}{$\begin{array}{c}\text { Maximum limit } \\
(\mathrm{mg} / \mathrm{kg})\end{array}$} & \multicolumn{4}{|c|}{ Analysis results $(\mathrm{mg} / \mathrm{kg})$} \\
\cline { 3 - 11 } & & $\mathrm{Cd}$ & $\mathrm{Pb}$ & $\mathrm{Hg}$ & $\mathrm{As}$ & $\mathrm{Cd}$ & $\mathrm{Pb}$ & $\mathrm{Hg}$ & $\mathrm{As}$ \\
\hline 09.0 & Fish and processed & 0.1 & 0.3 & 0.5 & 1.0 & $\mathrm{nd}$ & $\mathrm{nd}$ & $\mathrm{nd}$ & $\begin{array}{l}\left.1.63^{*}\right) \\
\left.1.80^{* *}\right)\end{array}$ \\
\hline & $\begin{array}{l}\text { Shrimp and other } \\
\text { crustaceans }\end{array}$ & 1.0 & 0.5 & 1.0 & 1.0 & $\mathrm{nd}$ & $\mathrm{nd}$ & $\mathrm{nd}$ & $\left.1.64^{* * *}\right)$ \\
\hline
\end{tabular}

Note :

$1.63 \mathrm{mg} / \mathrm{kg} * \quad$ : Nibeo soldado

$1.80 \mathrm{mg} / \mathrm{kg} * * \quad$ :Oreochromis mossambicus

$1.64 \mathrm{mg} / \mathrm{kg} \quad$ : Macrobrachium rosenbergii

From Table 6, it is known that the results of the analysis of the concentration of metals in fish and their processed products and shrimp are compared with the maximum limit based on Indonesian national standards. Fish and shrimp are safe from $\mathrm{Cd}, \mathrm{Pb}$, and $\mathrm{Hg}$ metals, meaning the status is safe for consumption, but for the concentration of As metal in Nibeo soldado and Macrobrachium rosenbergii, the status is not safe for consumption.

\subsection{Discussion}

Macrobrachium rosenbergii is a biota sample with a high concentration of metals ( $\mathrm{Zn}$, and $\left.\mathrm{Cu}^{\prime}\right)$ compared to other biota samples. According to [22], marine biota species of crustaceans, namely shrimp and crabs, are often used as bioindicators of metal pollution in the sea because organisms such as crustaceans are relatively not as fast as fish in avoiding the effects of metal pollution in waters. The nature of crustaceans that forage on the bottom of the water, namely in a sedimentary environment, will cause crustaceans to be very likely to be contaminated. The study results [23] in Muara Gembong that the concentration of $\mathrm{Zn}$ on the bottom substrate of the water ranged from $17.39-103.21 \mathrm{mg} / \mathrm{l}$, and in the water column, it went from $<0.001-0.113 \mathrm{mg} / \mathrm{l}$. The results of previous studies showed that the concentrations of $\mathrm{Zn}$ detected in both waters and sediments in Jakarta Bay were 0.005-0.007 mg/l and 95,800$333,000 \mathrm{mg} / 1$ [23]. $\mathrm{Zn}$ is an essential metal element and is sourced from household waste containing Zn metal, such as corrosion in water pipes and consumer products (e.g., detergent formulas) whose disposal facilities are not considered [22].

$\mathrm{Cu}$ detection in shrimp, shrimp is a bioindicator of metal contamination, as previously described. The results of research [23] in 2018 in Muara Gembong metal $\mathrm{Cu}$ in sediments ranged from $5-35 \mathrm{mg} / \mathrm{L}$, indicating that $\mathrm{Cu}$ at all research stations in Muara Gembong waters was at a status far above the threshold value for biota $(33 \mathrm{mg} / \mathrm{L})$ [23]. It is suspected that in the water substrate in Muara Gembong, $\mathrm{Cu}$ has accumulated over a long period from land, primarily from agriculture and industry in areas along the CBL river (Cikarang, Bekasi, Laut) and land. Copper $(\mathrm{Cu})$ is one type of metal that exists in nature, which is present due to volcanic activity and agricultural activity [24]. The results of previous studies in Jakarta Bay $[25,26]$ the concentration of $\mathrm{Cu}$ in both waters and sediments was $<0.005 \mathrm{mg} / \mathrm{L}$ and 15,000 $169,500 \mathrm{mg} / \mathrm{L}$ in 2010 and 2014 in waters ranging from $0.001-0.005 \mathrm{mg} / \mathrm{L}$. Cu is one of the most common substances that occur naturally in the environment. Copper is a substance that can spread through the environment through natural phenomena. $\mathrm{Cu}$ is included in the essential metal group, where organisms need low levels as a coenzyme in the body's metabolic processes. Its toxic properties only appear at high levels. Aquatic biota is very 
sensitive to excess $\mathrm{Cu}$ in the water bodies where they live. Dissolved $\mathrm{Cu}$ concentration in seawater of $0.01 \mathrm{mg} / \mathrm{L}$ can cause the death of phytoplankton. The end was caused by $\mathrm{Cu}$ toxicity which has inhibited enzyme activity in phytoplankton cell division. Species belonging to the Crustacea family will die within 96 hours if the $\mathrm{Cu}$ concentration is in the range of $0.17-100 \mathrm{mg} / \mathrm{L}$. In the same period of time, biota belonging to the mollusk family will die if the dissolved $\mathrm{Cu}$ content in the water body where the biota lives are between 0.16 $0.5 \mathrm{mg} / \mathrm{L}$, and the $\mathrm{Cu}$ content is $2.5-3.0 \mathrm{mg} / \mathrm{L}$. In the waters, body water can kill fish [27]. According to [28], $\mathrm{Cu}$ is one of the metals that causes the mass death of fish.

Arsenic is found in relatively small amounts but has a very high level of toxicity because it is a metal [29]. At Muara Gembong, as was detected in Macrobrachium rosenbergii 1.64 $\mathrm{mg} / \mathrm{kg}$, Oreochromis mossambicus $1.80 \mathrm{mg} / \mathrm{kg}$, and in Nibeo soldado $1.63 \mathrm{mg} / \mathrm{kg}$ (Table 6), which exceeded the quality standard of $0.012 \mathrm{mg} / \mathrm{kg}$ is estimated to originate from the Citarum and CBL rivers where industrial activities are very dense along these large rivers. It is feared that all types of fish in these waters (not only the three species) need to detect arsenic metal.

All metals occur naturally in the environment resulting from industrial wastes in increasing amounts. Arsenic can also damage the kidneys and is highly toxic [29]. Arsenic in groundwater is divided into two forms: the reduced form formed under anaerobic conditions, often called arsenite. The other form is the oxidized form, occurring under aerobic conditions, usually referred to as arsenate. Based on this description, the status of As is an essential concern for industrial owners who produce As waste and the government to carry out supervision and action for violating regulations.

Fish tissue samples in Muara Gembong in October 2018 metals $\mathrm{Cd}, \mathrm{Cr}, \mathrm{Pb}$, and $\mathrm{Hg}$ were not detected (Table 5), as was the case based on the Indonesian National Standard (SNI), fish in Muara Gembong was still below the quality standard for metals $\mathrm{Cd}, \mathrm{Pb}, \mathrm{Hg}$ but for $\mathrm{As}$ already exceed the quality standard (Tables 5 and 6). This condition does not guarantee safe waters, so that metal monitoring must continue to be carried out by the competent authority regularly, and industrial owners are required to process their waste and have a Waste Water Treatment Plant (WWTP) before being discharged into the community waters. According to [30], one of the most significant sources of pollution in the Citarum river is industrial waste. It was recorded those 2,700 medium and large industries disposed of their waste into river bodies, with details of around 53\% not being managed. Cikarang River Bekasi Laut (CBL), which is located in Bekasi Regency, West Java province, passes through densely populated and industrial areas [31]. The Cikarang Bekasi Laut (CBL) River is contaminated with waste. The river is now full of garbage and foam and a lousy smell [32].

\section{Conclusion}

The fish in Muara Gembong detected metals $\mathrm{Zn}, \mathrm{Cu}$, and As, which exceeded the quality standard, for Z was seen in eight fish species (Pangasius hypopthalmus, Oreochromis niloticus, Eleutheronema tetradactylum, Hexanematichthys sagor, Glossogobius giuris, Macrobrachium rosenbergii, Oreochromis mossambicus, and Nibea soldado) at all research stations. Metal $\mathrm{Cu}$ was detected in Macrobrachium rosenbergii, in the Muara Bendera and Muara Blacan. Metal As was witnessed in Macrobrachium rosenbergii, Oreochromis mossambicus, and Eleutheronema tetradactylum. Metals $\mathrm{Cd}, \mathrm{Cr}, \mathrm{Pb}$, and $\mathrm{Hg}$ in fish tissue samples at Muara Gembong in October 2018 were not detected, as well as in fish preparations and their preparations that use the Indonesian National Standard (SNI) standard, fish in Muara Gembong is still safe from Metal $\mathrm{Cd}, \mathrm{Pb}, \mathrm{Hg}$ but for As it has exceeded the quality standard. 
The community and business/factory owners must not litter into rivers, lakes, other puddles, and the sea. Especially for business/factory owners are required to have a Waste Water Treatment Plant (WWTP). The government continuously monitors, socializes, and strictly imposes fines and legal threats against environmental violators in its duties and authorities.

\section{Acknowledgements}

In writing this paper, Adriani Sri Nastiti and Krismono were the main contributors, while Dimas Angga Hedianto and Masayu Rahmia Anwar Putri were the member contributors. The authors would like to thank the Head of the Research Institute for Fisheries Enhancement (RIFE) for permission in Muara Gembong, Bekasi Regency, West Java Province. The data and information contained in this study are part of a research activity entitled Head of the Fisheries Improvement Research Center for the permission given during the research in Muara Gembong, Bekasi Regency, West Java Province. The data and information contained in this study are part of a research activity entitled "Research Model for the Rehabilitation of Estuary Areas on the North Coast of Java-Muara Gembong, Bekasi)" which was carried out in 2018. The authors would like to thank the Head and Staff Fisheries Service of Bekasi Regency and the community. Muara Gembong has supported this research.

\section{References}

1. G.R. Barokah, D. Dwiyitno, I. Nugroho, J. Pascapanen dan Bioteknol. Kelaut. dan Perikan. 14, 95 (2019)

2. B. Nugraha, S. Triharyuni, P.S. Suleman, S.T. Hartati, J. Ris. Jakarta 13, 17 (2020)

3. C. Bauvais, S. Zirah, L. Piette, F. Chaspoul, I. Domart-Coulon, V. Chapon, P. Gallice, S. Rebuffat, T. Pérez, M.L. Bourguet-Kondracki, Mar. Environ. Res. 104, 20 (2015)

4. D.G. Sfakianakis, E. Renieri, M. Kentouri, A.M. Tsatsakis, Environ. Res. 137, 246 (2015)

5. D.R.V. Abadi, S. Dobaradaran, I. Nabipour, X. Lamani, M. Ravanipour, R. Tahmasebi, S. Nazmara, Environ. Sci. Pollut. Res. 22, 6670 (2015)

6. M. Jaishankar, T. Tseten, N. Anbalagan, B.B. Mathew, K.N. Beeregowda, Interdiscip. Toxicol. 7, 60 (2014)

7. I. Marzuki, J. Akta Kim. Indones. (Indonesia Chim. Acta) 13, 1 (2020)

8. C. Lu, Y. Hong, J. Liu, Y. Gao, Z. Ma, B. Yang, W. Ling, M.G. Waigi, Environ. Pollut. 251, 773 (2019)

9. A. M. Orani, A. Barats, E. Vassileva, O. P. Thomas, Mar. Pollut. Bull. 131, 633 (2018)

10. L. Melawaty, A. Noor, T. Harlim, N. de Voogd, Adv. Biol. Chem. 4, 86 (2014)

11. A. Angela, I. Marzuki, KOVALEN J. Ris. Kim. 7, 12 (2021)

12. E.S.E. Mehana, A.F. Khafaga, S.S. Elblehi, M.E. Abd El-Hack, M.A.E. Naiel, M. BinJumah, S. I. Othman, A.A. Allam, Animals 10, 1 (2020)

13. R. Yousif, M.I. Choudary, S. Ahmed, Q. Ahmed, Nusant. Biosci. 13, 73 (2021)

14. D.Y. Pratiwi, J. Akuatek. 1, 59 (2020)

15. K.E. Carpenter, V.H. Nem (eds). FAO species identification sheets for fishery Purposes (FAO, Rome, 2001)

16. W. Fischer, G. Bianchi (eds), FAO Species identification sheets for fiishery purposes (FAO, Rome, 1984) 
17. R. Froese, D. Paul (eds), FishBase. www.fishbase.org (2018)

18. J.J. Albaret, M. Simier, F.S. Darboe, J.M. Ecoutin, J. Raffray, L.T. deMorais. Aquat. Living Resour. 17, 10 (2004)

19. G. Vidy, F.S. Darboe, E.M. Mbye. Aquat. Living Resour. 17, 10 (2004)

20. Minister of Environment of Indonesia, 1 (2014)

21. National Standard Agency, 25 (2009)

22. Darmono S, Environment and pollution: their relationship to the toxicology fo metal compounds (in Bahasa Indonesia) (Universitas Indonesia, Jakarta, 2001)

23. Mujiyanto et al., Research on estuari rehabilitation models on the North Coast of Java (in Bahasa Indonesia) (Balai Riset Pemulihan Sumber Daya Ikan Purwakarta, Purwakarta, 2018)

24. E. Dœlsch, V. Van de Kerchove, H. Saint Macary, Geoderma 134, 119 (2006)

25. Y. Permanawati, R. Zuraida, A. Ibrahim, J. Geol. Kelaut. 11, 9 (2013)

26. A.H. Kusuma, T. Prartono, A.S. Atmadipoera, T. Arifin, J. Teknol. Perikan. dan Kelaut. 6, 41 (2016)

27. Z. Tarigan, Edward, A. Rozak, MAKARA Sci. Ser. 7, 119 (2010)

28. Lestari, Edward, MAKARA Sci. Ser. 8, 52 (2010)

29. F. Istarani, E.S. Pandebesie, J. Tek. Pomits. 3, 1 (2014)

30. M. Hafiz, Waste pollution in Citarum is worrying, this is the solution. tribunews.com (2018)

31. Alfandi, J. Agrosintesa 1, 1 (2018)

32. R. Nugroho, Seriously! CBL Bekasi River is polluted with waste. news.detik.com (2019) 